\title{
Smoking history influences the prognostic value of peripheral naïve CD4+T cells in advanced non-small cell lung cancer
}

\author{
Chao Liu' ${ }^{1,2,3}$, Bin $\mathrm{Xu}^{1}$, Qian $\mathrm{Li}^{1}$, Aijie $\mathrm{Li}^{4}$, Lan $\mathrm{Li}^{1}$, Jinbo Yue ${ }^{2^{*}}$, Qinyong $\mathrm{Hu}^{1 *}$ and Jinming $\mathrm{Yu}^{1,2^{*}}$
}

\begin{abstract}
Background: Considering the effect of smoking on tumor immunity, we attempted to investigate the impact of smoking history on the prognostic value of circulating naïve and memory CD4+ and CD8+ T cells in advanced nonsmall cell lung cancer (NSCLC) treated with chemo(radio)therapy.

Methods: Of 196 histologically confirmed advanced NSCLC, 98 eligible ones were enrolled. Naïve and memory CD4+ and CD8+ T cells from peripheral blood were measured by flow cytometry. Kaplan-Meier curves helped estimate patients'survival. The uni- and multivariate Cox proportional hazards regression model was employed in the assessment of the prognostic value of factors.

Results: Multivariate survival analyses showed that peripheral naïve CD4+ T cells independently predicted favorable overall survival $(O S)$ in ever smokers with advanced NSCLC $(P=0.007)$, but unfavorable OS in never smokers with the same ailment $(P=0.012)$. Ever smokers presented a different distribution of naive and memory $T$ cells: low expression levels of naïve $C D 4+T(P=0.005)$, naïve $C D 8+T(P=0.031), C D 4+$ naïve/memory ratio $(P=0.020)$, and $C D 8+$ naïve/ memory ratio $(P=0.019)$, and high distributions of memory $C D 4+T(P=0.004)$, memory $C D 8+T(P=0.034)$, and naïve $C D 8 / C D 4$ ratio $(P=0.020)$, when compared to never smokers.
\end{abstract}

Conclusions: We revealed the impact of cigarette-smoking on peripheral naïve CD4+ T cells' prognostic value in advanced NSCLC patients. These results could help in refining personalized treatment for advanced NSCLC patients.

Keywords: Memory T cells, Naïve T cells, Non-small cell lung cancer, Cigarette

\section{Background}

Because of its aggressive tumor evasion and metastasis, lung cancer currently occupies the number one position in malignant tumor-related deaths worldwide [1-3]. Most patients with non-small cell lung cancer (NSCLC) get diagnosed with late stages, manifesting as local or systemic advanced diseases (stage III or IV), with an overall median survival of $<12$ months [4].

\footnotetext{
*Correspondence: yuejinbo@hotmail.com; rm001223@whu.edu.cn; sdyujinming@163.com

${ }^{1}$ Department of Oncology, Renmin Hospital of Wuhan University, Wuhan 430060, China

${ }^{2}$ Department of Radiation Oncology, Shandong Cancer Hospital and Institute, Shandong First Medical University and Shandong Academy of Medical Sciences, Jinan 250117, Shandong, China

Full list of author information is available at the end of the article
}

Recently, inhibitors of immune checkpoints aimed at regulating programmed death-1 (PD-1)/PD-ligand 1 (PD-L1) have triggered extraordinary responses, becoming a new standard treatment for advanced NSCLC without targetable oncogenes [5-15]. Interestingly, ever smokers with NSCLC react to immune checkpoint inhibitors better than their nonsmoking counterparts, which may be explained by the following findings [16, 17]. Lung cancer in ever smokers features a high incidence of mutating somatic cells, including DNA repair gene mutations, an enormous load of neoantigens, and a stronger immunogenicity. On the contrary, never smokers are home to low mutational frequencies and an immunosuppressive tumor microenvironment [18-20]. Taking the tumor immune microenvironment differences between ever smokers and never smokers into consideration, 
several studies have investigated the impact of cigarette smoke on tumor infiltrating lymphocytes' (TILs) prognostic role in NSCLC and established that the prognosis linking smoke to the subsets of TILs differed according to patients' smoking history [21-24]. Inamura and his colleagues revealed that the high expression of B7-H3 in a tumor microenvironment was connected to reduced lung cancer-specific survival in moderate/heavy-smoking patients, but not in non/light-smoking patients [23]. Kinoshita et al. [24] also found a high ratio of forkhead box P3 (FOXP3)/CD4 to be of poor prognosis in relation to a smoking history, but not low levels of $\mathrm{CD} 20+\mathrm{B}$ cells which were confirmed to be unfavorable to never smokers who had a complete resected NSCLC.

Because invasive procedures put patients at risks of complications, such as pneumothorax and bleeding [2527], and because the scheduling of biopsies can impose significant treatment delays and logistical challenges for patients, obtain a tumor tissue to test for TILs, especially in patients with unresectable advanced NSCLC, has proven invasive. To make matters more complicated, clinicians frequently repeat biopsies for the purpose of optimizing their approaches to resistant disease. Consequently, interest is mounting in tumor profiling via the analysis of peripheral blood to avoid the dangers and inconveniences posed by potentially multiple invasive biopsy procedures.

The probable prognostic interaction between smoking and circulating lymphocyte subsets from peripheral blood in NSCLC, collected by the minimal invasive liquid biopsy, remains largely unknown. We hypothesized that smoking could influence the role of peripheral $\mathrm{T}$ cells in NSCLC and attempted to investigate the impact of smoking on the prognostic value of circulating naïve and memory lymphocyte subsets in advanced NSCLC treated with chemo(radio)therapy.

\section{Methods \\ Study design}

This study was carried out with the Ethics Committee of Affiliated Hospital of Academy of Military Medical Sciences' approval. We obtained written informed consent from participating patients and healthy volunteers. Out of the 196 histological confirmed advanced NSCLC cases between February 2014 and December 2016, we enrolled 98 eligible patients treated with chemo(radio)therapy in the study. We excluded patients with incomplete clinicopathological data, known targetable oncogenes (anaplastic lymphoma kinase, epidermal growth factor receptor, and cMET), liver, hematological, and renal diseases, infection, performance status $(\mathrm{PS})>2$, patients who received granulocyte-colony stimulating factor, steroids, and antilymphocyte globulin treatments within the
3 months that preceded enrollment, and patients with other tumors. Sixty-two age- and sex-matched healthy individuals were registered for control purposes.

\section{Clinical information}

Data on age, smoking status, gender, histology, tumor stage matching the seventh American Joint Committee on Cancer (AJCC) staging system [28], tumor differentiation, and performance status were collected. Stage III patients received concurrent chemotherapy (cisplatinbased regime) and radiotherapy with 60-6 Gy/30-33 fractions. All stage IV patients underwent a cisplatinbased chemotherapy for 4-6 cycles. Follow-up was done regularly every 3 months and ended on October 2018.

\section{Sample collection and detection of naïve cells and memory T cells}

Four milliliters of fresh peripheral blood were collected from patients 3 days before all treatment and healthy volunteers, and stored in EDTA anti-coagulant tubes. Peripheral blood cells were mixed with specific antihuman monoclonal antibodies (BD Biosciences; USA) against CD3 PerCP (cat. no. 552851), CD4 APC (cat. no. 555349), CD8 APC (cat. no. 555369), CD45RA FITC (cat. no. 555488), CD197 PE (CCR7, cat. no. 560765), and CD45RO PE (cat. no. 555493), along with the isotype antibody that served as the negative control, for $15 \mathrm{~min}$ in the dark at room temperature. Then we used Red Blood Cell lysing buffer (BD Biosciences; USA) to lyse red cells for $10 \mathrm{~min}$ in the dark at room temperature and flow cytometry (BD Biosciences; USA) to analyze residual white blood cells. The following naïve and memory $\mathrm{T}$ cells: naïve CD4+ $\mathrm{T}(\mathrm{CD} 3+\mathrm{CD} 4+\mathrm{CD} 45 \mathrm{RA}+\mathrm{CCR} 7+)$, memory CD4+ $\mathrm{T}(\mathrm{CD} 3+\mathrm{CD} 4+\mathrm{CD} 45 \mathrm{RA}-\mathrm{CD} 45 \mathrm{RO}+)$, naïve $\mathrm{CD} 8+\mathrm{T}(\mathrm{CD} 3+\mathrm{CD} 8+\mathrm{CD} 45 \mathrm{RA}+\mathrm{CCR} 7+)$, and memory CD8+ T (CD3+CD8+CD45RA-CD45RO+) cells were identified. The data analysis software, FlowJo Version 10 (FlowJo, Ashland, OR, USA) was used to calculate the amounts of naïve and memory $T$ cells. Representative flow cytometry plots and gating are presented in Additional file 1: Figure S1.

\section{Statistical analysis}

Cut-off values for high or low naïve and memory $\mathrm{T}$ cells were determined by their respective median counts. For sub-group analyses of ever smokers and never smokers, we determined their cut-off values using the median counts of naïve and memory $\mathrm{T}$ cells in each sub-group. Progression-free survival marked the time from enrollment to the recurrence of a tumor, end or loss of follow-up, and death. Overall survival (OS) represented the interval between selection for participation and death and end or loss of follow-up. Analysis of data were 
undertaken using the SPSS 23.0 software (SPSS Inc., Chicago, IL). T cells were reported as mean \pm standard deviation. The assessment of the correlation between $\mathrm{T}$ cell levels and clinical information and the comparison of $\mathrm{T}$ cells counts between patients and healthy controls were performed using the student's $t$ test. The univariate and multivariate Cox proportional hazards regression model helped with the evaluation of the hazard ratio (HR) and 95\% confidence interval (CI). Variables with univariate analytical outcomes with $P<0.010$ were passed on for multivariate analysis. We estimated patients' survival with the use of the Kaplan-Meier curve and compared survival between groups using the Log-rank test. Statistical significance was considered at $P$ value $<0.05$.

\section{Results}

\section{Patient characteristics}

The baseline features of 98 advanced NSCLC cases are outlined in Table 1. Patients' median age was calculated at $61.5(43-90)$ years. The male patient representation was $63(64.3 \%)$ as against $35(35.7 \%)$ for the female patients. Taking part in the study were $55(56.1 \%)$ ever smokers and 43 (43.9\%) never smokers. Patients with stage IV received cisplatin-based chemotherapy. Stage III patients

Table 1 Baseline characteristics of 98 advanced NSCLC patients

\begin{tabular}{lc}
\hline Characteristic & N (\%) \\
\hline Age (years) & \\
$\geq 60$ & $56(57.1 \%)$ \\
$<60$ & $42(42.9 \%)$ \\
Gender & \\
Male & $63(64.3 \%)$ \\
Female & $35(35.7 \%)$ \\
Performance status & \\
0 & $26(26.5 \%)$ \\
1-2 & $72(73.5 \%)$ \\
Smoking status & \\
Ever smoker & $55(56.1 \%)$ \\
Never smoker & $43(43.9 \%)$ \\
CStage & \\
IV & $71(72.4 \%)$ \\
III & $27(27.6 \%)$ \\
Histology & \\
AD & $50(51.0 \%)$ \\
Non-AD & $48(49.0 \%)$ \\
Tumor differentiation & \\
Poor & $36(36.7 \%)$ \\
Moderate & $51(52.0 \%)$ \\
Well & $4(4.1 \%)$ \\
None & $7(7.1 \%)$ \\
\hline
\end{tabular}

received concurrent radiotherapy (60-66 Gy/30-33 fractions) and cisplatin-based chemotherapy. We estimated the follow-up mean and median times at 15.5 and 13.3 months. 58 (59.2\%) patients had died by the end of the last follow-up.

NSCLC patients had low levels of naïve CD4+ T $(19.6 \pm 11.6$ vs. $29.1 \pm 11.3, \mathrm{P}<0.001)$ and a low $\mathrm{CD} 4+$ naïve/memory ratio $(0.3 \pm 0.3$ vs. $0.6 \pm 0.3, \mathrm{P}<0.001)$ and high levels of memory CD4+ $\mathrm{T}(67.6 \pm 13.6$ vs. $55.6 \pm 11.0, \mathrm{P}<0.001)$ and memory $\mathrm{CD} 8+\mathrm{T}(36.6 \pm 14.3$ vs. $30.7 \pm 8.0, \mathrm{P}=0.001)$, as well as a high naïve $\mathrm{CD} 8$ / $\mathrm{CD} 4$ ratio $(3.1 \pm 2.8$ vs. $1.8 \pm 1.5, \mathrm{P}<0.001)$ than healthy controls (Fig. 1a).

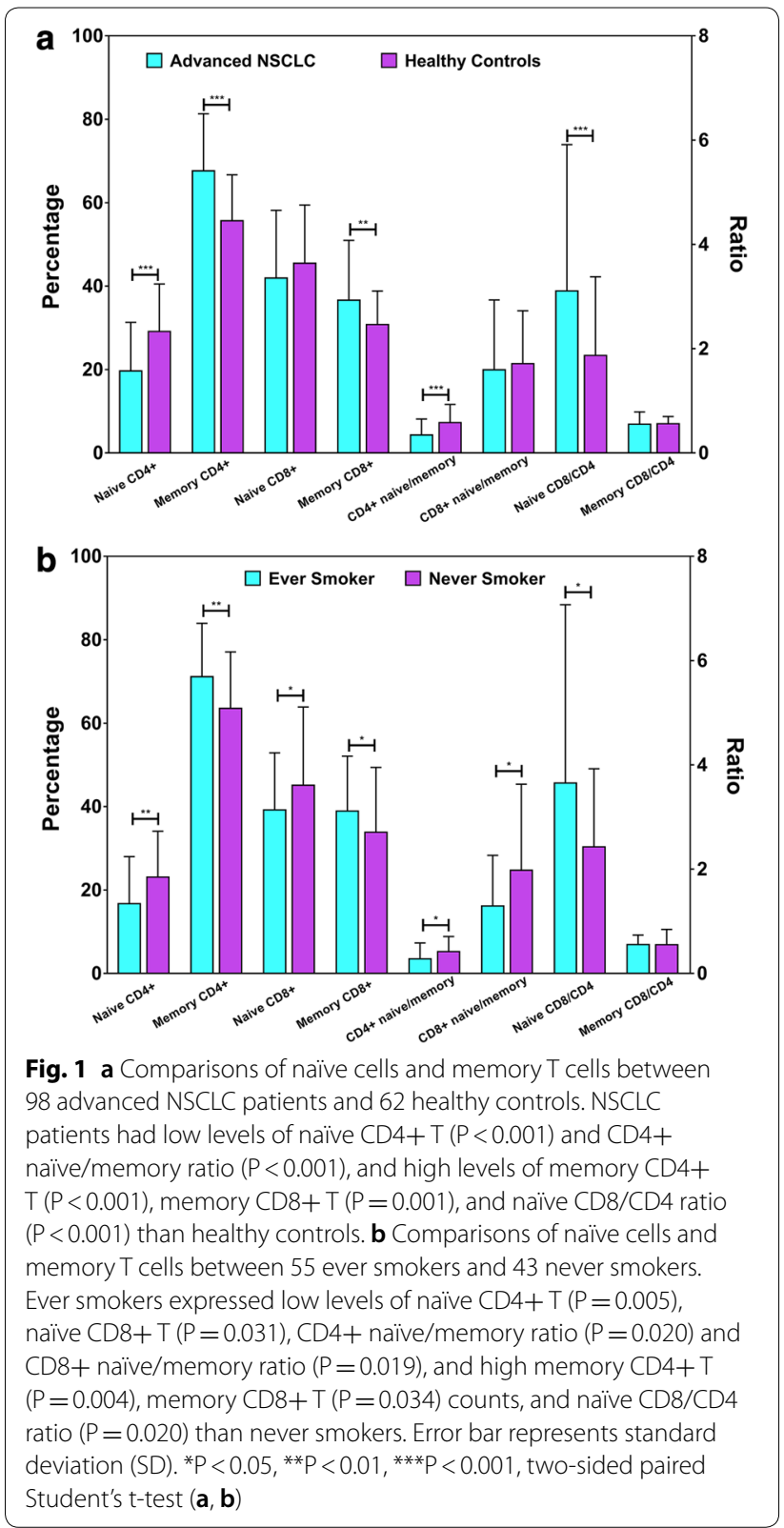




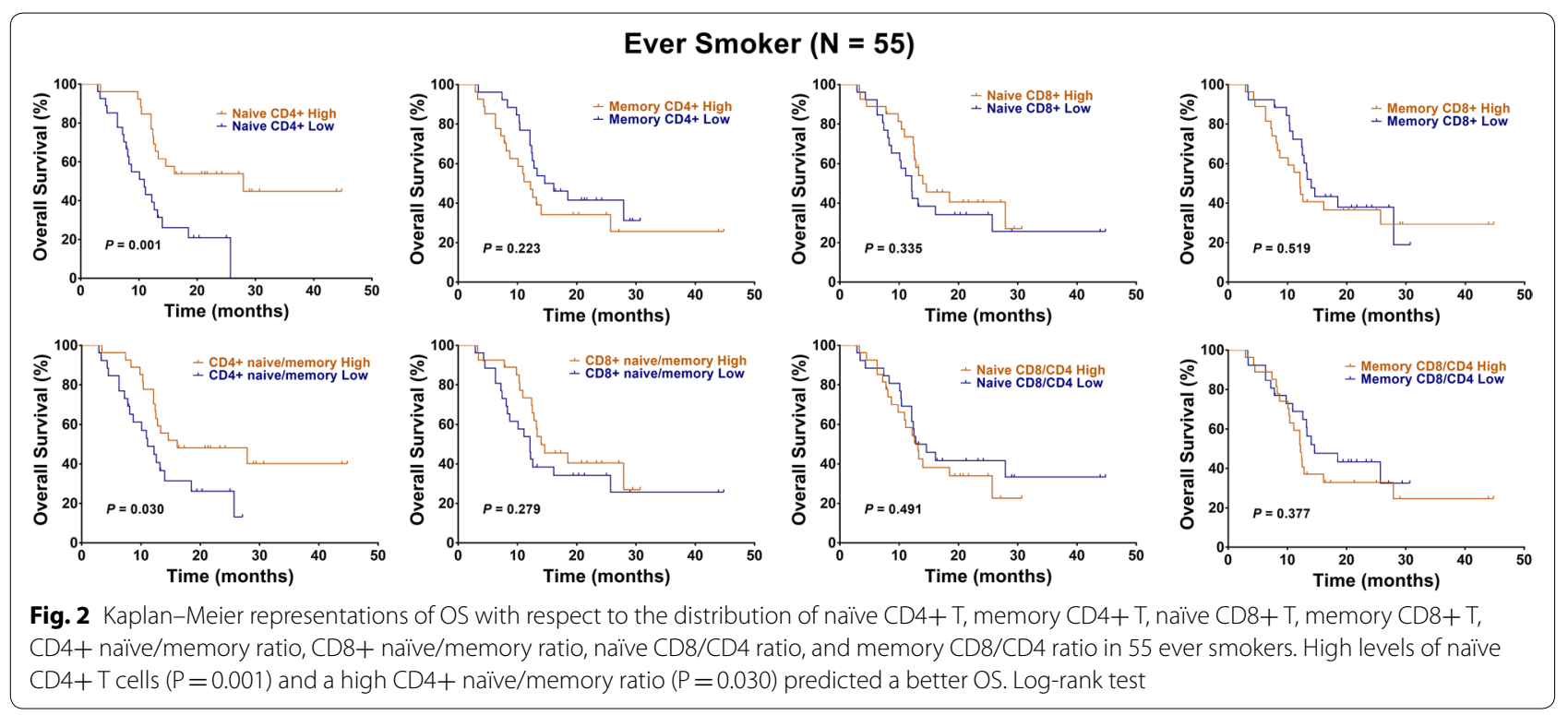

\section{Difference in the distribution of naïve and memory T cells between ever smokers and never smokers}

The expression of immune cells greatly differed between ever smokers and never smokers (Fig. 1b) but not in the comparisons between other parameters (Additional file 1: Figure S2). Ever smokers expressed low levels of naïve $C D 4+\mathrm{T}(16.7 \pm 11.3$ vs. $23.4 \pm 11.1, \mathrm{P}=0.005)$ and naïve $\mathrm{CD} 8+\mathrm{T}(39.2 \pm 13.7$ vs. $45.4 \pm 18.6, \mathrm{P}=0.031)$, as well as a low CD4+ naïve/memory ratio $(0.3 \pm 0.3$ vs. $0.4 \pm 0.3, \mathrm{P}=0.020)$, and a low $\mathrm{CD} 8+$ naïve $/ \mathrm{mem}$ ory ratio $(1.3 \pm 1.0$ vs. $2.0 \pm 1.6, \mathrm{P}=0.019)$ than never smokers. Ever smokers also had high memory CD4+ $\mathrm{T}(71.1 \pm 12.8$ vs. $63.1 \pm 13.6, \mathrm{P}=0.004)$ and memory CD8+ $\mathrm{T}(38.9 \pm 13.1$ vs. $33.6 \pm 15.4, \mathrm{P}=0.034)$ counts, as well as a high naïve $\mathrm{CD} 8 / \mathrm{CD} 4$ ratio (3.7 \pm 3.4 vs. $2.4 \pm 1.5, \mathrm{P}=0.020$ ) than never smokers (Fig. 1b). These findings suggest that naive and memory $\mathrm{T}$ cells were quite differently distributed between ever smokers and never smokers.

\section{Naïve CD4+ T cells' favorable prognostic value in ever smokers}

To determine, for all of 98 advanced NSCLC cases, if the OS and DFS of patients with high immune cells were significantly different from those of patients with low immune cells, the Kaplan-Meier analysis was performed, with results shown in Additional file 1: Figure S3-S4. Consequently, we found that there was no significant correlation between immune cells and survival (all $\mathrm{P}>0.05$ ).

However, considering of the distinct naïve and memory $\mathrm{T}$ cell levels between ever smokers and never smokers, we performed subgroup analyses. Interestingly, we found that high levels of naïve CD4 $+\mathrm{T}$ cells (HR: 0.35, 95\% CI 0.17-0.70, P=0.001, Fig. 2, Table 2) and a high CD4+ naïve/memory ratio (HR: 0.48, 95\% CI 0.24-0.97, $\mathrm{P}=0.030$, Fig. 2, Table 2) predicted a better OS in 55 ever smokers. In addition, high levels of naïve CD8+ T cells (HR: 0.54, 95\% CI 0.29-1.01, P=0.037, Fig. 3, Table 2) and a high CD8+ naïve/memory ratio (HR: 0.53, 95\% CI $0.28-0.99, \mathrm{P}=0.032$, Fig. 3 , Table 2 ) predicted a better PFS. Multivariate analysis showed that the presence of naïve CD4+ $\mathrm{T}$ cells independently predicted a favorable OS in ever smokers (HR: 0.11, 95\% CI 0.02-0.55, $\mathrm{P}=0.007$, Table 2).

\section{Naïve CD4+ T cells' unfavorable prognostic value in never smokers}

Kaplan-Meier analysis and univariate analysis showed that high levels of naïve CD4+ T cells predicted a shorter OS in each of 43 never smokers (HR: 3.16, 95\% CI 1.387.40, $\mathrm{P}=0.009$, Fig. 4, Table 3). Besides, high levels of naïve CD4+ T cells and CD4+ naïve/memory ratio were associated with a poor PFS, with strong trend (HR: 2.07, 95\% CI 0.97-4.41, $\mathrm{P}=0.062$; HR: 2.07, 95\% CI 0.97-4.42, $\mathrm{P}=0.056$, Fig. 5, Table 3). Multivariate analysis showed that naïve CD4+ T cells independently predicted unfavorable OS in never smokers (HR: 2.17 , 95\% CI 1.155.49, $\mathrm{P}=0.012$, Table 3).

\section{Discussion}

The results of this study confirmed our hypothesis that smoking influences naïve and memory T cells' prognostic value in patients with advanced NSCLC. Intriguingly, 
Table 2 Cox regression analysis of survival for ever smokers among NSCLC patients

\begin{tabular}{llllll}
\hline Variables & OS & & PFS \\
\cline { 2 - 3 } \cline { 5 - 6 } & HR $(95 \% \mathrm{Cl})$ & P value & & HR $(95 \% \mathrm{Cl})$ & P value \\
\hline
\end{tabular}

Univariate analysis

Age (years)

$<60$

$\geq 60$

1

Gender

Female

Male

$1.26(0.30-5.30)$

0.746

$1.22(0.36-4.08) \quad 0.747$

Performance status

0

$1-2$

cStage

III

IV

Histology

Non-AD

$A D$

$1.76(0.76-4.04)$

0.18

$1.41(0.70-2.80) \quad 0.331$

1

$1.84(0.96-3.53) \quad 0.066$

$1.35(0.66-2.75) \quad 0.404$

\section{1}

$1.37(0.70-2.66) \quad 0.352$

Tumor differentiation

Well/moder- 1

ate

Poor

$1.58(0.80-3.12) \quad 0.187$

Naive CD4+

Low

High 1

Memory CD4+

Low

High

Naive CD8+

Low

High$$
0.72
$$

Memory CD8+

Low 1

High

$1.24(0.63-2.44) \quad 0.519$

CD4+ naive/memory

\begin{tabular}{lllll} 
Low & 1 & & 1 & \\
High & $0.48(0.24-0.97)$ & 0.03 & $0.78(0.42-1.44)$ & 0.411 \\
CD8+ naive/memory & & & \\
Low & 1 & & 1 & \\
High & $0.69(0.35-1.36)$ & 0.279 & $0.53(0.28-0.99)$ & 0.032 \\
Naive CD8/CD4 & & & 1 & \\
Low & 1 & & $0.89(0.48-1.63)$ & 0.708 \\
High & $1.26(0.64-2.47)$ & 0.491 & & \\
$\begin{array}{l}\text { Memory CD8/CD4 } \\
\text { Low }\end{array}$ & 1 & & 1 & \\
High & $1.35(0.68-2.64)$ & 0.377 & $1.56(0.84-2.87)$ & 0.133 \\
Multivariate analysis & & & \\
$\begin{array}{l}\text { Naive CD4+ } \\
\text { Low }\end{array}$ & 1 & & 1 & \\
High & $0.11(0.02-0.55)$ & 0.007 & $0.73(0.35-1.52)$ & 0.400 \\
\hline
\end{tabular}

Table 2 (continued)

\begin{tabular}{|c|c|c|c|c|}
\hline \multirow[t]{2}{*}{ Variables } & \multicolumn{2}{|l|}{ OS } & \multicolumn{2}{|l|}{ PFS } \\
\hline & HR $(95 \% \mathrm{Cl})$ & $P$ value & $\mathrm{HR}(95 \% \mathrm{Cl})$ & $P$ value \\
\hline \multicolumn{5}{|c|}{ CD4+ naive/memory } \\
\hline Low & 1 & & - & \\
\hline High & $3.63(0.77-16.95)$ & 0.101 & - & - \\
\hline \multicolumn{5}{|c|}{ Naive CD8+ } \\
\hline Low & - & & 1 & \\
\hline High & - & - & $0.69(0.11-4.17)$ & 0.693 \\
\hline \multicolumn{5}{|c|}{ CD8+ naive/memory } \\
\hline Low & - & & 1 & \\
\hline High & - & - & $0.80(0.12-5.03)$ & 0.815 \\
\hline \multicolumn{5}{|l|}{ cStage } \\
\hline III & - & & 1 & \\
\hline IV & - & - & $1.97(0.99-3.92)$ & 0.051 \\
\hline
\end{tabular}

we found that the presence of peripheral naivve $\mathrm{CD} 4+\mathrm{T}$ cells had a favorable prognostic impact for ever smokers, but an unfavorable prognostic value for never smokers. We also revealed a distinctive distribution of naïve and memory $\mathrm{T}$ cells between ever smokers and never smokers. Ever smokers expressed low levels of naïve CD4+ T and naïve $\mathrm{CD} 8+\mathrm{T}$, as well as a low $\mathrm{CD} 4+$ naïve/memory ratio and a low $\mathrm{CD} 8+$ naïve/memory ratio and high levels of memory CD4+ T and memory CD8+ T, as well as a high naïve $\mathrm{CD} 8 / \mathrm{CD} 4$ ratio than never smokers. These results could provide evidence for an interesting interactive significance between naïve and memory $\mathrm{T}$ cells and smoking in advanced NSCLC.

Two previous investigations have examined the prognostic value of naïve and memory $\mathrm{T}$ cells in resectable NSCLC [29, 30]. Yang and his colleagues reported that an increased $\mathrm{CD} 4+$ naive/memory ratio predicted better PFS in 76 resectable NSCLC [30]. Hara et al. [29] figured out that the $\mathrm{CD} 4(+)$ naive/memory ratio had a prognostic relevance in 38 patients with NSCLC that underwent surgery. They proved the possible association between peripheral naïve cells and peripheral memory $\mathrm{T}$ cells and survival in NSCLC. However, they did not examine the interaction of naïve cells and memory cells with smoking history. Additionally, the sample size used by these two studies was too small, which may explain why they did not find any differences in naïve and memory cells between ever smokers and never smokers.

In our study, we enrolled 98 patients with advanced NSCLC and found a significant difference in naive and memory $\mathrm{T}$ cells' distribution between ever smokers and never smokers, which has not been reported in any studies before. Smoking induces a high incidence of mutations in somatic cells, including DNA repair genes' 

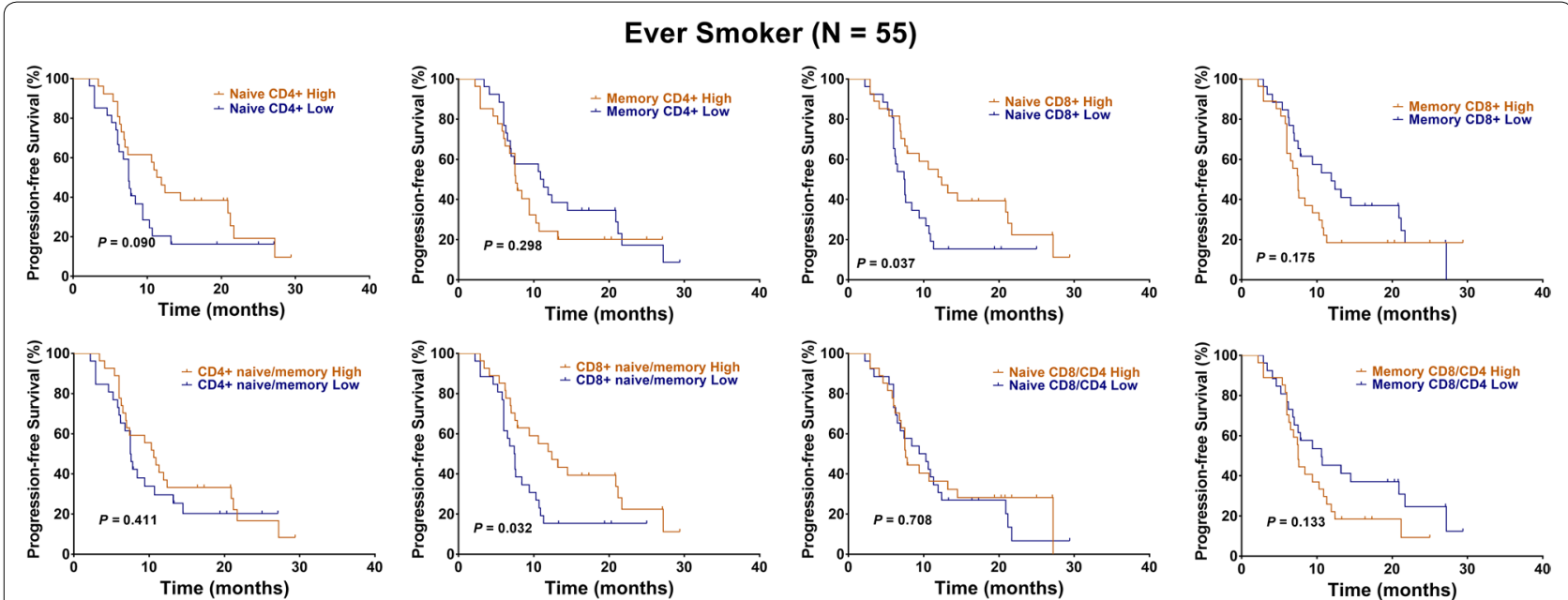

Fig. 3 Kaplan-Meier representations of PFS with respect to the distribution of naive CD4+ T, memory CD4+ T, naive CD8+ T, memory CD8+ T, CD4+ naïve/memory ratio, $C D 8+$ naïve/memory ratio, naïve CD8/CD4 ratio, and memory CD8/CD4 ratio in 55 ever smokers. High levels of naïve CD8+ T cells $(P=0.037)$ and a high $C D 8+$ naïve/memory ratio $(P=0.032)$ predicted a better $P F S$. Log-rank test

mutations, a huge load of neoantigens $[18,19,31]$ that activated naïve $\mathrm{T}$ cells' differentiation into effector $\mathrm{T}$ cells to eliminate the neoantigens [32-36]. These findings support our results that lower levels of naïve $\mathrm{CD} 4+\mathrm{T}$ and naïve $\mathrm{CD} 8+\mathrm{T}$, as well as a lower $\mathrm{CD} 4+$ naïve/memory ratio and a lower CD8+ naïve/memory ratio, together with higher levels of memory $\mathrm{CD} 4+\mathrm{T}$ and memory $\mathrm{CD} 8+\mathrm{T}$ existed in ever smokers compared to never smokers.

We report the contrasting naïve $\mathrm{CD} 4+\mathrm{T}$ cells' prognostic values between ever smokers and never smokers with advanced NSCLC. To date, no investigative studies have described this phenomenon. Tobacco smoking creates a high frequency of somatic mutations, a huge burden of neoantigens, and an amplified immunogenicity, which possibly maintain the greater proliferative potential of naïve CD4+ cells and CD8+ T cells that have been linked to greater immune efficacy [37]. These findings back our results that naïve CD4+ T cells' prognostic value was favorable in ever smokers with NSCLC. On the other hand, never smokers harbor a low burden of mutation and immunosuppressive feature, quite possibly a

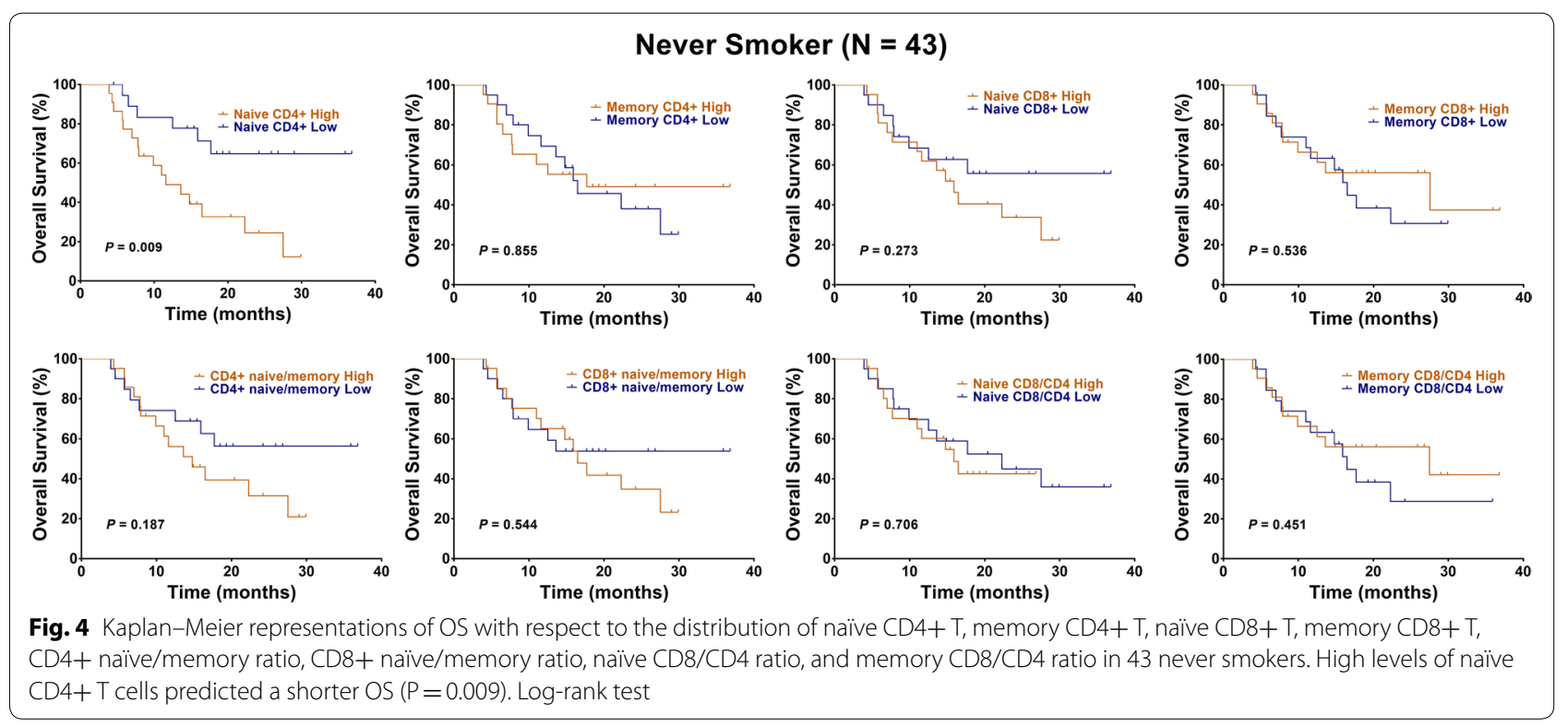


Table 3 Cox regression analysis of survival for never smokers among NSCLC patients

\begin{tabular}{llllll}
\hline Variables & OS & & PFS \\
\cline { 2 - 3 } \cline { 5 - 6 } & HR $(95 \% \mathrm{Cl})$ & P value & & HR $(95 \% \mathrm{Cl})$ & P value \\
\hline
\end{tabular}

Univariate analysis

Age (years)

$<60-1$

$\begin{array}{lllll}\geq 60 & 0.46(0.19-1.09) & 0.081 & 0.44(0.21-0.95) & 0.036\end{array}$

Gender

Female $\quad 1$

$\begin{array}{lllll}\text { Male } & 1.81(0.76-4.32) & 0.18 & 2.06(0.94-4.52) & 0.07\end{array}$

Performance status

0

$1-2 \quad 1.36(0.39-4.70) \quad 0.625$

cStage

III

IV

Histology

Non-AD

$A D$

$1.32(0.50-3.50) \quad 0.568$

1

1

$0.98(0.36-1.70) \quad 0.981$

$0.73(0.32-1.65) \quad 0.451$

Tumor differentiation

Well/moder- 1

ate

Poor

$1.86(0.76-4.50) \quad 0.169$

Naive CD4+

Low

High $\quad 3.19(1.38-7.40) \quad 0.009$

Memory CD4+

Low 1

High $\quad 0.92(0.40-2.13) \quad 0.855$

Naive CD8+

Low

High $1.61(0.69-3.72) \quad 0.273$

Memory CD8+

Low $\quad 1$

High $\quad 0.76(0.33-1.77) \quad 0.536$

CD4+ naive/memory

$\begin{array}{lllll}\text { Low } & 1 & 1 & \\ \text { High } & 1.77(0.76-4.08) & 0.187 & 2.07(0.97-4.42) & 0.056\end{array}$

CD8+ naive/memory

$\begin{array}{lllll}\text { Low } & 1 & & 1 & \\ \text { High } & 1.29(0.56-2.99) & 0.544 & 1.33(0.62-2.83) & 0.455\end{array}$

Naive CD8/CD4

Low $\quad 1$

$\begin{array}{lllll}\text { High } & 1.16(0.50-2.70) & 0.706 & 0.98(0.46-2.09) & 0.964\end{array}$

Memory CD8/CD4

Low 1

High $\quad 0.72(0.31-1.68) \quad 0.451$

Multivariate analysis

Naive CD4+

$\begin{array}{lllll}\text { Low } & 1 & 1 & & \\ \text { High } & 2.17(1.15-5.49) & 0.012 & 2.43(0.22-26.80) & 0.468\end{array}$

Table 3 (continued)

\begin{tabular}{|c|c|c|c|c|}
\hline \multirow[t]{2}{*}{ Variables } & \multicolumn{2}{|l|}{ os } & \multicolumn{2}{|l|}{ PFS } \\
\hline & HR $(95 \% \mathrm{Cl})$ & $P$ value & $\mathrm{HR}(95 \% \mathrm{Cl})$ & $P$ value \\
\hline \multicolumn{5}{|c|}{ CD4+ naive/memory } \\
\hline Low & - & & & \\
\hline High & - & - & $0.82(0.09-7.18)$ & 0.858 \\
\hline \multicolumn{5}{|l|}{ Age (years) } \\
\hline$<60$ & 1 & & 1 & \\
\hline$\geq 60$ & $0.47(0.19-1.13)$ & 0.094 & $0.70(0.28-1.74)$ & 0.447 \\
\hline \multicolumn{5}{|l|}{ Gender } \\
\hline Female & - & & 1 & \\
\hline Male & - & - & $1.79(0.72-4.48)$ & 0.209 \\
\hline \multicolumn{5}{|c|}{ Tumor differentiation } \\
\hline $\begin{array}{l}\text { Well/moder- } \\
\text { ate }\end{array}$ & - & & 1 & \\
\hline Poor & - & - & $2.07(0.84-5.08)$ & 0.112 \\
\hline
\end{tabular}

contributing factor in naive $\mathrm{CD} 4+\mathrm{T}$ cells' differentiation into immunosuppressive CD4+ Treg [34], which back our findings of naïve CD4+ T cells' unfavorable prognostic value in never smokers with NSCLC.

Some limitations exist in our study. First, the 98 advanced NSCLC constitutes a small sample pool. Second, subgroup analyses of prognostic values in ever smokers and never smokers based on histological types were not performed because of the limited sample size. Further studies are needed to address this issue. Third, exposure to smoking by never smokers was not considered since the smoking status used depended fully on patients' self-evaluation. Finally, we did not explore the underlying mechanisms for our findings. Further studies are needed to investigate the underlying mechanisms. Despite these limitations, our results suggest opposing values of prognosis of naïve $\mathrm{CD} 4+\mathrm{T}$ cells between ever smokers and never smokers with advanced NSCLC.

\section{Conclusions}

We revealed the impact of cigarette smoking on the prognostic values of naïve and memory $\mathrm{T}$ cells in advanced NSCLC patients. Peripheral naïve CD4 $+\mathrm{T}$ cells had a favorable prognostic significance in ever smokers, but an unfavorable prognostic value in never smokers. We also found a significant difference in naïve and memory $\mathrm{T}$ cells' distribution between ever smokers and never smokers. These results could help refine personalized treatment for advanced NSCLC. 


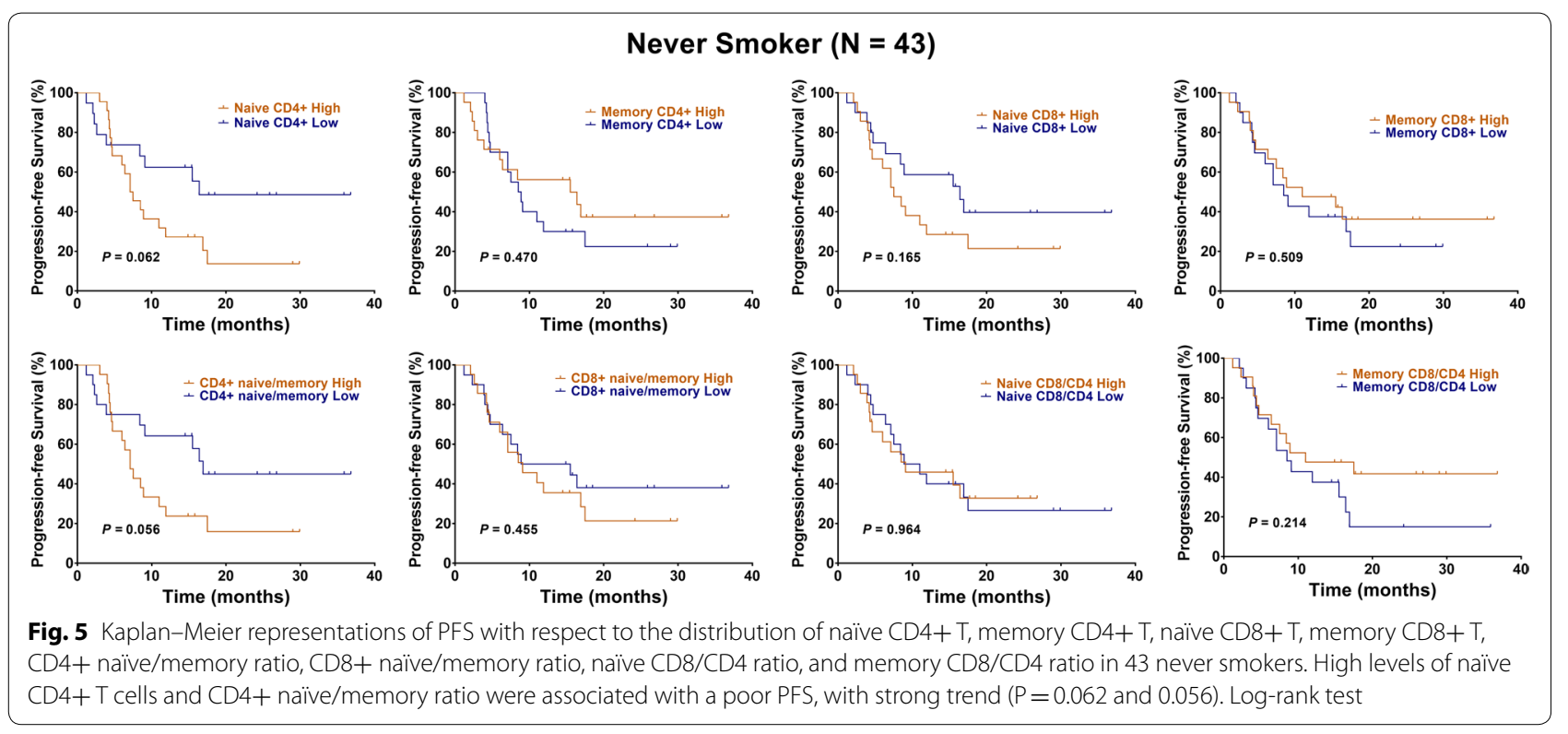

\section{Additional file}

Additional file 1: Figure S1. Representative plots for flow cytometry analysis showing (A) naive CD4+ T and memory CD4+T; (B) naïve CD8+ $T$ and memory CD8+T cells. FlowJo Version 10 (FlowJo, Ashland, OR, USA) was used to evaluate naiive and memory T cells. Figure S2. Comparisons of naïve cells and memory $T$ cells between $A D$ and Non-AD, female and male, age $<60$ and age $\geq 60$, ECOG PS 0 and $1-2$, stages III and IV, and poor and moderate/good differentiation. Error bar represents SD. ${ }^{*} P<0.05$, ${ }^{*} \mathrm{P}<0.01,{ }^{* * *} \mathrm{P}<0.001$, two-sided paired Student's t-test. Figure $\mathbf{S 3}$. Kaplan-Meier representations of OS with the respect to the distribution of naïve $C D 4+T$, memory $C D 4+T$, naïve $C D 8+T$, memory $C D 8+T$, CD4+ naïve/memory ratio, CD8 + naïve/memory ratio, naïve CD8/CD4 ratio, and memory CD8/CD4 ratio in 98 advanced NSCLC patients. No significant difference of OS between patients with high and low immune cells (all $P>0.05$ ). Log-rank test. Figure S4. Kaplan-Meier representations of PFS with respect to the distribution of naiive CD4+ T, memory CD4+ $T$, naïve $C D 8+T$, memory $C D 8+T, C D 4+$ naïve/memory ratio, $C D 8+$ naïve/memory ratio, naïve $\mathrm{CD} 8 / \mathrm{CD} 4$ ratio, and memory $\mathrm{CD} 8 / \mathrm{CD} 4$ ratio in 98 advanced NSCLC patients. No significant difference of PFS between patients with high and low immune cells (all P > 0.05). Log-rank test.

\section{Abbreviations}

NSCLC: non-small cell lung cancer; OS: overall survival; PD-1: programmed death-1; FOXP3: forkhead box P3; PFS: progression-free survival.

\section{Acknowledgements}

Not applicable.

\section{Authors' contributions}

$J M Y, Q Y H$, and JBY conceived and designed the study. CL, BX, QL, AL, and LL collected peripheral blood samples and clinicopathological data. CL performed the experiments, statistical analysis, and wrote the manuscript. All authors read and approved the final manuscript.

\section{Funding}

This work was supported by Shandong Key Research and Development Program (No. 2016CYJS01A03), National Natural Science Foundation of China (Nos. 81472813 and 81871895), and National Key Research and Development Program of China (No. 2018YFC1313200).

\section{Availability of data and materials}

All data included in our study are shown in our manuscript.

\section{Ethics approval and consent to participate}

This investigation received approval from the Ethics Committee of the Affiliated Hospitals of Academy of Military Medical Sciences. All patients and healthy volunteers provided written informed consents.

\section{Consent to publish}

Not applicable.

\section{Competing interests}

The authors declare that they have no competing interests.

\section{Author details}

${ }^{1}$ Department of Oncology, Renmin Hospital of Wuhan University, Wuhan 430060, China. ${ }^{2}$ Department of Radiation Oncology, Shandong Cancer Hospital and Institute, Shandong First Medical University and Shandong Academy of Medical Sciences, Jinan 250117, Shandong, China. ${ }^{3}$ Department of Radiation Oncology, Affiliated Hospital of Academy of Military Medical Sciences, Beijing 100071, China. ${ }^{4}$ Weifang Medical University, Weifang 261053, Shandong, China.

Received: 20 March 2019 Accepted: 4 July 2019

Published online: 09 July 2019

\section{References}

1. Siegel RL, Miller KD, Jemal A. Cancer statistics, 2018. CA Cancer J Clin. 2018:68:7-30.

2. Chen W, Zheng R, Baade PD, Zhang S, Zeng H, Bray F, et al. Cancer statistics in China, 2015. CA Cancer J Clin. 2016;66:115-32.

3. Maus MV, Fraietta JA, Levine BL, Kalos M, Zhao Y, June CH. Adoptive immunotherapy for cancer or viruses. Annu Rev Immunol. 2014;32:189-225.

4. von Verschuer U, Schnell R, Tessen HW, Eggert J, Binninger A, Spring $L$, et al. Treatment, outcome and quality of life of 1239 patients with advanced non-small cell lung cancer-final results from the prospective German TLK cohort study. Lung Cancer (Amsterdam, Netherlands). 2017;112:216-24 
5. Garassino MC, Cho BC, Kim JH, Mazieres J, Vansteenkiste J, Lena H, et al. Durvalumab as third-line or later treatment for advanced non-small-cell lung cancer (ATLANTIC): an open-label, single-arm, phase 2 study. Lancet Oncol. 2018;19:521-36.

6. Barlesi F, Vansteenkiste J, Spigel D, Ishii H, Garassino M, de Marinis F, et al. Avelumab versus docetaxel in patients with platinum-treated advanced non-small-cell lung cancer (JAVELIN Lung 200): an open-label, randomised, phase 3 study. Lancet Oncol. 2018;19(11):1468-79.

7. Fehrenbacher L, Spira A, Ballinger M, Kowanetz M, Vansteenkiste J, Mazieres J, et al. Atezolizumab versus docetaxel for patients with previously treated non-small-cell lung cancer (POPLAR): a multicentre, openlabel, phase 2 randomised controlled trial. Lancet (London, England). 2016:387:1837-46.

8. Brahmer J, Reckamp KL, Baas P, Crino L, Eberhardt WE, Poddubskaya E, et al. Nivolumab versus docetaxel in advanced squamous-cell non-smallcell lung cancer. N Engl J Med. 2015;373:123-35.

9. Borghaei H, Paz-Ares L, Horn L, Spigel DR, Steins M, Ready NE, et al. Nivolumab versus docetaxel in advanced nonsquamous non-small-cell lung cancer. N Engl J Med. 2015;373:1627-39.

10. Shaverdian N, Lisberg AE, Bornazyan K, Veruttipong D, Goldman JW, Formenti SC, et al. Previous radiotherapy and the clinical activity and toxicity of pembrolizumab in the treatment of non-small-cell lung cancer: a secondary analysis of the KEYNOTE-001 phase 1 trial. Lancet Oncol. 2017;18:895-903.

11. Peters S, Gettinger S, Johnson ML, Janne PA, Garassino MC, Christoph D, et al. Phase II trial of atezolizumab as first-line or subsequent therapy for patients with programmed death-ligand 1-selected advanced non-smallcell lung cancer (BIRCH). J Clin Oncol. 2017;35:2781-9.

12. Gulley JL, Rajan A, Spigel DR, lannotti N, Chandler J, Wong DJL, et al. Avelumab for patients with previously treated metastatic or recurrent nonsmall-cell lung cancer (JAVELIN Solid Tumor): dose-expansion cohort of a multicentre, open-label, phase 1b trial. Lancet Oncol. 2017;18:599-610.

13. Rizvi NA, Hellmann MD, Brahmer JR, Juergens RA, Borghaei $H$, Gettinger $\mathrm{S}$, et al. Nivolumab in combination with platinum-based doublet chemotherapy for first-line treatment of advanced non-small-cell lung cancer. J Clin Oncol. 2016;34:2969-79.

14. Melosky B, Chu Q, Juergens R, Leighl N, McLeod D, Hirsh V. Pointed progress in second-line advanced non-small-cell lung cancer: the rapidly evolving field of checkpoint inhibition. J Clin Oncol. 2016;34:1676-88.

15. Langer CJ, Gadgeel SM, Borghaei H, Papadimitrakopoulou VA, Patnaik A, Powell SF, et al. Carboplatin and pemetrexed with or without pembrolizumab for advanced, non-squamous non-small-cell lung cancer: a randomised, phase 2 cohort of the open-label KEYNOTE-021 study. Lancet Oncol. 2016;17:1497-508.

16. Garon EB, Rizvi NA, Hui R, Leighl N, Balmanoukian AS, Eder JP, et al. Pembrolizumab for the treatment of non-small-cell lung cancer. N Engl J Med. 2015:372:2018-28.

17. Herbst RS, Soria JC, Kowanetz M, Fine GD, Hamid O, Gordon MS, et al. Predictive correlates of response to the anti-PD-L1 antibody MPDL3280A in cancer patients. Nature. 2014;515:563-7.

18. Alexandrov LB, Ju YS, Haase K, Van Loo P, Martincorena I, Nik-Zainal S, et al. Mutational signatures associated with tobacco smoking in human cancer. Science (New York, NY). 2016:354:618-22.

19. Alexandrov LB, Nik-Zainal S, Wedge DC, Aparicio SA, Behjati S, Biankin $A V$, et al. Signatures of mutational processes in human cancer. Nature. 2013;500:415-21.

20. Desrichard A, Kuo F, Chowell D, Lee KW, Riaz N, Wong RJ, et al. Tobacco smoking-associated alterations in the immune microenvironment of squamous cell carcinomas. J Natl Cancer Inst. 2018;1 10(12):1386-92.

21. Inamura K, Shigematsu Y, Ninomiya H, Nakashima Y, Kobayashi M, Saito $\mathrm{H}$, et al. CSF1R-expressing tumor-associated macrophages, smoking and survival in lung adenocarcinoma: analyses using quantitative phosphorintegrated dot staining. Cancers. 2018;10:252.

22. Kinoshita T, Kudo-Saito C, Muramatsu R, Fujita T, Saito M, Nagumo H, et al. Determination of poor prognostic immune features of tumour microenvironment in non-smoking patients with lung adenocarcinoma. Eur J Cancer (Oxford, England: 1990). 2017;86:15-27.

23. Inamura K, Yokouchi $Y$, Kobayashi M, Sakakibara R, Ninomiya H, Subat $S$, et al. Tumor B7-H3 (CD276) expression and smoking history in relation to lung adenocarcinoma prognosis. Lung Cancer (Amsterdam, Netherlands). 2017:103:44-51.
24. Kinoshita T, Muramatsu R, Fujita T, Nagumo H, Sakurai T, Noji S, et al. Prognostic value of tumor-infiltrating lymphocytes differs depending on histological type and smoking habit in completely resected non-small cell lung cancer. Ann Oncol. 2016;27(11):2117-23.

25. Heerink WJ, de Bock GH, de Jonge GJ, Groen HJ, Vliegenthart R, Oudkerk M. Complication rates of CT-guided transthoracic lung biopsy: metaanalysis. Eur Radiol. 2017;27:138-48.

26. Moreland A, Novogrodsky E, Brody L, Durack J, Erinjeri J, Getrajdman G, et al. Pneumothorax with prolonged chest tube requirement after CTguided percutaneous lung biopsy: incidence and risk factors. Eur Radiol. 2016;26:3483-91.

27. Saji H, Nakamura H, Tsuchida T, Tsuboi M, Kawate N, Konaka C, et al. The incidence and the risk of pneumothorax and chest tube placement after percutaneous CT-guided lung biopsy: the angle of the needle trajectory is a novel predictor. Chest. 2002;121:1521-6.

28. Edge SB, Compton CC. The American Joint Committee on Cancer: the 7th edition of the AJCC cancer staging manual and the future of TNM. Ann Surg Oncol. 2010;17:1471-4.

29. Hara M, Matsuzaki Y, Shimizu T, Tomita M, Ayabe T, Enomoto Y, et al. Preoperative peripheral naive/memory ratio and prognosis of nonsmall-cell lung cancer patients. Ann Thorac Cardiovasc Surg. 2007;13:384-90.

30. Yang $P, M a$ J, Yang $X, L i W$. Peripheral CD4+ naive/memory ratio is an independent predictor of survival in non-small cell lung cancer. Oncotarget. 2017:8:83650-9.

31. Martincorena I, Fowler JC, Wabik A, Lawson ARJ, Abascal F, Hall MWJ, et al. Somatic mutant clones colonize the human esophagus with age. Science (New York, NY). 2018;362(6417):911-7.

32. Sheng SY, Gu Y, Lu CG, Tang YY, Zou JY, Zhang YQ, et al. The characteristics of naive-like t cells in tumor-infiltrating lymphocytes from human lung cancer. J Immunother (Hagerstown, Md: 1977). 2017;40:1-10.

33. Poschke I, De Boniface J, Mao Y, Kiessling R. Tumor-induced changes in the phenotype of blood-derived and tumor-associated T cells of early stage breast cancer patients. Int J Cancer. 2012;131:1611-20.

34. Su S, Liao J, Liu J, Huang D, He C, Chen F, et al. Blocking the recruitment of naive $C D 4+T$ cells reverses immunosuppression in breast cancer. Cell Res. 2017:27:461-82.

35. Laky K, Evans S, Perez-Diez A, Fowlkes BJ. Notch signaling regulates antigen sensitivity of naive CD4+T cells by tuning co-stimulation. Immunity. 2015;42:80-94.

36. Henning AN, Roychoudhuri R, Restifo NP. Epigenetic control of CD8(+)T cell differentiation. Nat Rev Immunol. 2018;18(5):340.

37. Hinrichs CS, Borman ZA, Gattinoni L, Yu Z, Burns WR, Huang J, et al. Human effector CD8+ T cells derived from naive rather than memory subsets possess superior traits for adoptive immunotherapy. Blood. 2011;117:808-14

\section{Publisher's Note}

Springer Nature remains neutral with regard to jurisdictional claims in published maps and institutional affiliations.

Ready to submit your research? Choose BMC and benefit from:

- fast, convenient online submission

- thorough peer review by experienced researchers in your field

- rapid publication on acceptance

- support for research data, including large and complex data types

- gold Open Access which fosters wider collaboration and increased citations

- maximum visibility for your research: over $100 \mathrm{M}$ website views per year

At BMC, research is always in progress.

Learn more biomedcentral.com/submissions 